\title{
Inventory of Randang Meat Recipes in Agam Regency as a Traditional Food in West Sumatera
}

\author{
Elida $^{1}$, Wirnelis Syarif ${ }^{2}$, Yolanda Intan Sari ${ }^{3}$ \\ \{elidampd@gmail.com\} \\ Family Welfare Education, Universitas Negeri Padang ${ }^{123}$
}

\begin{abstract}
This study aimed to make an inventory of the randang meat recipe in Agam Regency as a traditional food leading to a commercial and global food. Agam Regency consists of 16 Districts and 82 Nagari (villages), where they used as research sites were Nagari Sungai Tanang, Nagari Gadut, Nagari Baso, and Nagari Duo Koto. This study used a qualitative method. Sources of research data were obtained from informants, namely Bundo Kanduang, or people who were experts in processing of randang using snowball sampling techniques. The data of this research was in the form of observations and interviews from informants, as well as observations at the research location. The results of the research that have been conducted show that there were variations in the quality recipe of the meat in Agam Regency
\end{abstract}

Keywords: Randang; Agam Regency; West Sumatera

\section{Introduction}

West Sumatra is a province in Indonesia which has natural beauty and various ethnic groups, customs, culture, and traditional food. The wealth and natural preservation of West Sumatra is well known by many people, both local and foreign. West Sumatra's culture, customs and special foods are regional identities and cultural assets that must be preserved by the people of West Sumatra. Agam Regency is one of the areas in West Sumatra. Agam Regency or Luhak Agam is one of the early residential areas of the Minangkabau population, this district has 16 sub-districts and 82 nagari. Its area reaches $1,804.30 \mathrm{~km} 2$ and a population of 524,906 people with a distribution of 291 people / $\mathrm{km} 2$, where each of these areas has a characteristic in one of its traditional foods, namely randang. Randang for Minangkabau people is more than just food, but is part of the culture. In baralek (wedding) events, traditional events, or holidays, randang must always be present among other dishes. Among the advantages of randang over other foods is its long durability, even months. Randang, which is a local Minangkabau food, became popular everywhere. Food that was originally local became national, even global. According to Wynda (2019).

Making the production of rendang or in the Minang language called marandang, can be defined as cooking by heating coconut milk, spices, and meat with certain ingredients by heating and stirring endlessly (Murdijati, et al, 2019: 38). Azima, F. (2016). This cooking process aims to increase or extend the shelf life of the randang. The unique of beef rendang, it can last a long time in the open air for several weeks without using artificial preservatives. Based on preliminary observations made in various sub-districts in Agam regency, the recipes found for making beef randang are very diverse and numerous, each person has their own 
recipe for randang processing using they owned recipes and passed down from generation to generation to the present. The processing method still uses estimated measurements and nothing has been written with a standard size, so the quality of the resulting randang is different, this happens because there is no right and same dose in making the beef randang because they use the same recipe dosing. not yet standard, such as making coconut milk with coconut calculations, using spices based on instinct, and tasting the taste first, if the taste obtained is not suitable, the processor will add the ingredients back so that the taste is maximum.

Based on the problems above, it can be seen that randang is an important cultural asset and needs to be preserved and maintained. One of the first steps in maintaining the nation's culture is knowing, learning and sharing, this can be done by taking an inventory of the randang recipe in Agam Regency. Inventory is the activity of recording or collecting data on the types of activities, the results to be achieved and about culture and so on (A. Gima Sugiama, 2013: 173). In this case what will be identified is the randang recipe which includes ingredients, seasonings, tools and processing techniques (Rahmadona, 2018). Randang inventory is an activity to collect data on randang in Agam Regency as traditional food. Regulation of the Minister of Home Affairs Number 52 of 2007 that "Customs and social values of the community are one of the social assets that can be utilized in the framework of implementing development so that preservation and development efforts are needed in accordance with the characteristics of the indigenous peoples". For this reason, it is necessary to have an inventory of randang in Agam Regency as a traditional food.

\section{Research Methodology}

This research was a qualitative descriptive study because the data will be presented later in descriptive form. The purpose of this study was to inventory the randang recipe in Agam Regency as a traditional food. The research was carried out in Agam Regency including: Kenagarian Sungai Tanang, Kenagarian Baso, Kenagarian Gadut, Kenagarian Duo Koto in August-September 2020. The instrument of this study was the researcher himself and his assistance by interview, observation and documentation. The data collection techniques in this study were carried out by observing, interviewing, and documenting, in which the researcher immediately went down to the field by asking a number of questions to the group of informants who had been assigned. Data analysis techniques in this study include data reduction.

\section{Result and Discussion}

The findings obtained in this study were the different randang recipes both in terms of spices, processing techniques and the quality produced from the existing randang in each Kenagarian. The following is the recipe inventory data obtained from Kenagarian Sungai Tanang, Baso, Duo Koto and Gadut: 
Table 2. Recipe Inventory Data in Kenagarian Sungai Tanang

\begin{tabular}{ll}
\hline No. & \multicolumn{1}{c}{ Material } \\
1 & $\begin{array}{l}1 \mathrm{~kg} \text { of beef }(15 \\
\text { pieces) } \\
\text { (old) } 6 \text { pieces }\end{array}$ \\
& \\
2 & $1 \mathrm{~kg}$ of meat $(15-$ \\
& $\begin{array}{l}25 \quad 3 \\
\text { pieces of coconut }\end{array}$
\end{tabular}

Seasonings \& Spices Making Technique

3 ounces of red onion, $11 / 2$

tablespoons of Local garlic, 1 tablespoon of ginger, 2 tablespoons of galangal, Pepper tsp, Coconut randang $1 / 2$ tbsp, Garda mungu (E. carda-momum) 3 pieces, 5-6 pieces of lime leaves, Bay leaves 4 sheets, turmeric leaves 2 sheets, 3 sticks of lemongrass.

3 Meat $1 \mathrm{~kg}$ (12-18 Local red Chili $1 / 4 \mathrm{~kg}, 3$ tbsp pieces), Coconut 4 Shallot, Onion, 4 tbsp Local Fruit ( 3 old +1 white, 3 tbsp Ginger medium) 4 tbsp galangal, pepper (smooth) $1 / 2$ tsp, coriander (smooth) $1 / 2$ tsp, fruit, nutmeg (smooth) $1 / 2$ fruit, mace, 2 dill, leaves, 6 pieces of orange, 6 bay leaves, 3 turmeric leaves sheet, 4 sticks of lemongrass pieces), Coconut 3 tablespoons, 1-ounce red Fruit ( 2 old +1 onion, 2 tablespoons Garlic, medium)

1 tablespoon Ginger, 2 tablespoons Galangal 5 pieces of lime leaves, 6 pieces of bay leaves, 4 pieces of bay leaves, 2 pieces of turmeric leaves, 4-5 lemongrass stalks

$5 \quad$ Meat $1 \mathrm{~kg}(16-20$ Local Red Chili 1/4 kg, 3 tbsp pieces), Coconut 3 red onion, Garlic4 tbsp, 3 Fruit ( 2 old +1 tbsp ginger, 4 tbsp galangal, medium)

1 tbsp goat seasoning, 8 lime leaves

Prepare all the ingredients, finely grind the garlic, red chilies, ginger and galangal, shallots, lime leaves, bay leaves, turmeric leaves, lemongrass, grated coconut and make coconut milk, in an iron skillet, cook coconut milk and all the spices to a boil, then add the meat, cook until the meat is tender and the oil rises.

Prepare all ingredients, finely grind shallots, garlic, red chilies, ginger, galangal, lime leaves, bay leaves, turmeric leaves, lemongrass and pepper, grated coconut and make coconut milk, in an iron skillet, saute all the spices and spices until fragrant., then add the meat, cook until the meat is tender, then add the coconut milk, cook until the oil rises

Prepare all ingredients, finely grind shallots, garlic, red chilies, ginger, galangal, coriander, pepper and nutmeg, grated coconut and make coconut milk, in an iron skillet saute all the spices and herbs until fragrant, then add the meat, cook until spices dry, then add coconut milk, cook until the oil rises

Prepare all ingredients, finely grind the garlic, red chilies, ginger and galangal, sliced shallots, lime leaves, bay leaves, turmeric leaves, lemongrass stalks, grate coconut and make coconut milk, in an iron skillet, cook coconut milk and all the spices to a boil, then add the meat, cook until the meat is tender and the oil rises

Prepare all the ingredients, finely grind the shallots, garlic, red chilies, ginger and galangal. In an iron skillet, saute all the spices and spices until fragrant, then add the meat, cook until the meat is 
Meat $1 \mathrm{~kg}(20-25$

pieces), Coconut 3 Fruit $(2$ old +1 medium)

$1 \mathrm{~kg}$ of meat (2030 pieces), coconut 3 Fruit (2 old +1 medium) pieces), Coconut 35 pieces, 3 tbsp local garlic, 2 Fruit (2 old-1 tbsp ginger, Galangal 3 medium) Fruit $(2$ old +1 medium)

Meat $1 \quad \mathrm{~kg} \quad(20$ pieces), Coconut 3 pieces
6 pieces of Bay Leaves, 2 pieces of turmeric leaves, 3 pieces of lemongrass stalks

2 ounces of local red Chili, 3 tablespoons of shallot, 3 tablespoons of Kampong garlic, 1 tablespoon of Ginger, 3 tablespoons of galangal, 1/2 tablespoon of spices, pepper $1 / 2$ tsp, 4 pieces of lime leaves, 4 pieces of bay leaf, 1 sheet of turmeric leaves, stem 2 sticks of

Local red Chili 2 ounces, red onion (sliced) 1 ounce, Garlic $1 \frac{1 / 2}{2 b s p} / 2$ ginger, ginger (1 thumb) 3-4 fruits, galangal (1 thumb segment) 3-4 fruits, 1 tsp pepper, $1 / 2$ tbsp goat seasoning, nutmeg $1 / 2-1$ fruit, 5 pieces of lime leaves 3 pieces of bay leaves 2 pieces of turmeric leaves 1 stick of lemongrass tablespoons, 4 pieces of bay leaves, 5 pieces of lime leaves, 3 pieces of turmeric leaves, 3 pieces of lemon grass ounce Cayenne Pepper, 5 pieces of red onion, 1 ounce of garlic, Ginger $1 / 2$ ounce / 1 tbsp, 3 tbsp galangal, 4 pieces of lime leaves, 4 pieces of bay leaf

2 pieces of turmeric leaves, 1 stem of lemongrass

Red Chili $1 / 4 \mathrm{~kg}$, Shallot $1 / 4 \mathrm{~kg}$,

Garlic $1 \frac{1}{2}$ ounce, Ginger $1 \frac{1}{2}$ ounce, Galangal 1 1/2 ounce, Pepper, to taste, Spices to taste, 4 lime leaves, 4 bay leaves, 2 pieces of turmeric leaves, stem 2 sticks of lemongrass lemongrass

1-ounce local red Chili, 1/2 - 1 tender, then add the coconut milk, cook until the oil rises.

Prepare all the ingredients, finely grind the garlic, red chilies, ginger, galangal, lime leaves, bay leaves, turmeric leaves, lemongrass and pepper, grated coconut and make coconut milk, put the coconut milk, spices and meat directly in an iron skillet, then cook. until the oil comes out

Prepare all the ingredients, finely grind garlic, red chilies, ginger, galangal, lime leaves, bay leaves, turmeric leaves, lemongrass, pepper and nutmeg, grated coconut and make coconut milk using coconut water, in an iron skillet saute all the spices and ingredients. spices until fragrant, then add 1 cup coconut milk starch, cook, until it boils, add the cooked meat until the spices are absorbed, then add the remaining thick coconut milk \& thin coconut milk, cook until the oil rises.

Prepare all ingredients, finely grind shallots, garlic, red chilies, ginger and galangal, sliced lime leaves, turmeric leaves, lemongrass and bay leaves intact, grated coconut and make coconut milk, in an iron skillet cook coconut milk and all the spices until boil, then add the meat, cook until the meat is tender and the oil rises

Prepare all ingredients, finely grind the garlic, red chilies, ginger and galangal, sliced shallots, lime leaves, bay leaves, turmeric leaves, lemongrass stalks, grate coconut and make coconut milk, In an iron skillet, cook coconut milk and all the spices to a boil, Then add the meat, cook until the meat is tender and the oil rises

Prepare all ingredients, finely grind shallots, garlic, red chilies, ginger and galangal, lime leaves, bay leaves, turmeric leaves, lemongrass and pepper sticks intact, grated coconut and make coconut milk, in an iron skillet saute all the spices and spices until fragrant, then add the meat to the thin coconut milk, 
$111 \mathrm{~kg}$ Meat (10-15 Local Red Chili $1 / 4 \mathrm{~kg}, 1-$ pieces) ounce red onion, $1 \frac{1}{2}$ ounce Coconut 3 Fruit $\left(2\right.$ Garlic, 1 ounce ginger, $1 \frac{1}{2}$ parents +1 ounce galangal, 1 tsp pepper, slimming) $\quad 1 / 2$ nutmeg 5 pieces of lime leaves, 4 pieces of bay leaves, 3 pieces of turmeric leaves, 2 pieces of lemongrass stalks cook until the spices are absorbed, then add the coconut milk, cook until the oil rises

Prepare all ingredients, finely grind shallots, garlic, red chilies, ginger, galangal, nutmeg and pepper, crushed lime leaves, bay leaves, turmeric leaves, lemongrass, grated coconut and make coconut milk, in an iron skillet saute all the spices and spices until fragrant, then add the meat, cook until the meat is $1 / 2$ tender, then remove it, then add the coconut milk, cook until the oil rises, after the oil rises, put the meat back in and cook until the meat is tender

Based on the table above, it can be concluded that the randang recipe from Kenagarian Sungai Tanang uses various ingredients, spices and processing techniques. Where for the ingredients used in the processing of randang in Kenagarian Sungai Tanang, namely using meat, in $1 \mathrm{~kg}$ of beef used produces 15-20 pieces, for the use of coconut, namely 3 grains, while for the spices and herbs used are local red chilies, garlic, shallots, galangal, ginger, bay leaves, lime leaves, turmeric leaves, lemongrass and salt.

Table 3. Recipe Inventory Data in Kenagarian Baso

\begin{tabular}{|c|c|c|c|}
\hline No. & Material & Seasonings & Processing Engineering \\
\hline 1. & $\begin{array}{l}1 \mathrm{~kg} \text { of meat }(25 \\
\text { pieces) } \\
\text { Coconut } 3 \text { pcs (old } 2 \\
\text { pcs }+ \text { half old } 1 \text { pcs) }\end{array}$ & $\begin{array}{l}\text { Local chilies } 1 / 4 \mathrm{~kg} \text {, } \\
\text { Galangal } 1 / 4 \mathrm{~kg} \\
\text { Ginger } 2 \text { ounces } \\
\text { Shallot } 1 / 4 \mathrm{~kg} \\
2 \text { ounces of garlic } \\
5 \text { pieces of bay leaves, } \\
2 \text { pieces of turmeric leaves } \\
5 \text { pieces of kaffir lime leaves, } \\
3 \text { stalk lemongrasses, } \\
\text { Salt sck }\end{array}$ & $\begin{array}{l}\text { Combine the coconut milk, spices } \\
\text { that have been mashed and the } \\
\text { leaves are then cooked to a boil } \\
\text { over a high enough heat, then add } \\
\text { the meat to the oil. After } \\
\text { sprinkling the oil, reduce the heat } \\
\text { using only coconut husk. Then the } \\
\text { rendang is cooked for } \pm 3 \text { hours } \\
\text { until cooked, Randang is ready to } \\
\text { be served }\end{array}$ \\
\hline 2. & $\begin{array}{l}1 \mathrm{~kg} \text { of meat ( } 25 \\
\text { pieces) } \\
\text { Coconut } 4 \text { pcs (old) }\end{array}$ & $\begin{array}{l}\text { Local chilies } 1 / 4 \mathrm{~kg} \\
\text { Galangal } 1 / 4 \mathrm{~kg} \\
\text { Ginger } 1 \text { ounce } \\
\text { Shallot } 1 / 4 \mathrm{~kg} \\
\text { Garlic } 2 \text { ounces) } \\
\text { Bay leaf } 10 \text { strands } \\
\text { Turmeric leaves } 5 \text { strands } \\
\text { Lime leaves } 10 \text { strands } \\
\text { Lemongrass } 2 \text { btg } \\
\text { Salt sck }\end{array}$ & $\begin{array}{l}\text { Saute the spices and leaves that } \\
\text { have been mashed and the } \\
\text { lemongrass that has been crushed } \\
\text { until fragrant, then add the meat, } \\
\text { stir for a while, then add the } \\
\text { coconut milk and cook it until the } \\
\text { oil rises, turn off the heat, let the } \\
\text { meat soak for one night, the next } \\
\text { day. Cook it again using low heat } \\
\text { only with coconut husk so it } \\
\text { doesn't burn and it's not too dry. } \\
\text { Once cooked, the randang is ready } \\
\text { to be served }\end{array}$ \\
\hline 3. & $\begin{array}{l}1 \mathrm{~kg} \text { of meat }(30 \\
\text { pieces) }\end{array}$ & $\begin{array}{l}\text { Logal chili gling } 2 \text { ounces } \\
2 \text { ounces galangal (milled) }\end{array}$ & $\begin{array}{l}\text { Combine the coconut milk, spices } \\
\text { that have been mashed and the }\end{array}$ \\
\hline
\end{tabular}


Coconut 4 pcs (old $3 \quad 1$ ounce ginger (finely leaves are then cooked to a boil pcs + mangkal 1 pcs) $\quad$ ground)

Turmeric to taste

2 ounces of red onion

1 head of garlic

5 pieces of bay leaves

2 pieces of turmeric leaves

Lime leaves 8 strands

3 stalk lemongrasses

(crushed)

Salt sck

4. $\begin{aligned} & 1 \mathrm{~kg} \\ & \text { pieces })\end{aligned}$ of meat (25 $\begin{aligned} & \text { Local chilies } 1 / 4 \mathrm{~kg} \\ & \text { Galangal } 2 \text { tbsp }\end{aligned}$

pieces)

Coconut 4 pcs (old 3 Ginger1 tbsp

pcs + mangkal 1 pcs) Shallot 2 ounces

Garlic 3 tbsp

Bay leaf 4 strands

Turmeric leaves 2 strands

Lime leaves 4 strands

Lemongrass \pm 4 unit

(smashed)

Pepper 2 pcs

Coconut randang \pm 4 tbsp

Salt sck

5. $1 \mathrm{~kg}$ of meat (25 Local chilies $1 / 4 \mathrm{~kg}$

pieces) Galangal 1 ounce

Coconut 4 pcs (old Ginger 1 ounce

2bh + mangka 2bh) $\quad$ Shallot 1 ounce

Garlic 2 weevils

Bay leaf 2 strands

Turmeric leaves 3 strands

Lime leaves 4 strands

Lemongrass 2 btg (smashed)

Salt sck

6. $1 \mathrm{~kg}$ of meat (25 Local chilies $1 / 4 \mathrm{~kg}$

pieces)

Local chilies $1 / 4 \mathrm{~kg}$
Galangal 2 handfuls

Coconut 4 pes (old)

Ginger 1 handful

Garlic 1 hump

Bay leaf 2 strands

Turmeric leaves 2 strands

Lime leaves 3 strands

Lemongrass 2 btg (smashed)

Salt sck

7. $1 \mathrm{~kg}$ of meat (30 Local chilies 4 ounces

pieces)

Galangal 2 ounces

Coconut 5 pcs (old 3 Ginger 1 ounce

pcs + mangka 2 pcs) Garlic 2 ounces

2 ounces of red onion

Bay leaf 15 strands

Turmeric leaves 5 strands over a high enough heat, then add the meat to the oil. After sprinkling the oil, reduce the heat using only coconut husk. Then the rendang is cooked for \pm 3 hours until cooked, Randang is ready to be served

Combine the coconut milk, spices that have been mashed and the leaves then cook until it boils over a high enough heat, and then add the meat until the new oil sprinkles to reduce the heat and only use the fire from the coconut husks, After the randang meat becomes kalio (low half finished) then add the sliced shallots. already half-fried, cook in cook over low heat for \pm 4 hours until cooked and oily dry, Randang is ready to serve

Combine the coconut milk, spices that have been mashed and the leaves are then cooked to a boil over a high enough heat, then add the meat to the oil. After sprinkling the oil, reduce the heat using only coconut husk. Then the rendang is cooked for \pm 5 hours until dry, oily and cooked, Randang is ready to serve

Combine the coconut milk, spices that have been mashed and the leaves are then cooked to a boil over a high enough heat, then add the meat to the oil. After sprinkling the oil, reduce the heat using only coconut husk. Then the rendang is cooked for \pm 3 hours until dry, oily and cooked. Randang is ready to serve

Combine the coconut milk, spices and leaves that have been mashed and then cook until it boils over a high enough heat, then add the meat to a sprinkling of oil. After sprinkling the oil, reduce the heat using only coconut husk. Then the 
Lime leaves 10 strands

Lemongrass 5 btg

Coconut randang $1 / 2$ coconut

Nutmeg sck

Coriander sack

Salt sck

8. $1 \mathrm{~kg}$ of meat (25 Local chilies 1 ounce pieces)

Galangal 3 tbsp

Coconut 3 pcs (old 2 Ginger 1 tbsp

pcs + mangka 1 pcs

Garlic 2 weevils

Red onion $1 / 2$ of $1 / 4 \mathrm{~kg}$

Bay leaf 5 strands

Turmeric leaves 3 strands

Lime leaves 5 strands

(whole)

Lemongrass 2-3 btg

Salt sck

9. $1 \mathrm{~kg}$ of meat $(30$

pieces)

Coconut 3 pcs (old 2 Galangal 2 tbsp (ground)

pcs + mangka 1 pcs) Ginger 1 tbsp (ground)

Garlic 1 tbsp (ground)

1 tbsp red onion (ground)

Bay leaf 2 strands

Turmeric leaves 2 strands

Lime leaves 1 strand

Lemongrass 2 btg

Pepper 4 pcs (milled)

Salt sck

10. $1 \mathrm{~kg}$ of meat (25 Local chilies $1 / 4 \mathrm{~kg}$

pieces)

Galangal 3 tbsp

Coconut 5 pcs (old)

Ginger 1 tbsp

Garlic 3 tbsp

1 ounce of red onion

Bay leaf 4 strands

Turmeric leaves 1 strand

Lime leaves 4 strands

(whole)

Lemongrass 3 btg

Salt sck

11. $1 \mathrm{~kg}$ of meat (20-25 Local chilies 1 ounce

pieces)

Galangal $1 \frac{1}{2}$ tbsp

Coconut 4 pcs (old 3 Ginger 1 tbsp

pcs + mangka 1 pcs) Garlic 1 tbsp

Red onion 1 tbsp randang is cooked for \pm 3 hours until cooked. If you want it to be more delicious, let the randang sit for 1 night until the spices soak into the new meat the next day, cook it again until the randang is dry, oily and cooked. Randang ready to be served

Combine the coconut milk, spices and leaves that have been mashed except for the lime leaves, then cook until it boils over a high enough heat, then add the meat to a sprinkling of oil, after sprinkling the new oil, add the lime leaves which are still intact, reduce the heat using only coir coconut. Then the randang is cooked for \pm 5 hours until cooked, if randang wants it to be more delicious, let the randang sit for 1 night until the spices soak into the new meat the next day cooked again until the dry randang is oily and cooked, randang is ready to serve

Combine the coconut milk, spices that have been mashed and the leaves are then cooked to a boil over a high enough heat, then add the meat to the oil. After sprinkling the oil, reduce the heat using only coconut husk. For \pm 2 hours, let the randang let it cool so that the spices soak into the meat, then just cook it again until it's dry and cooked. Randang ready to be served

Combine the coconut milk, spices and leaves that have been mashed then cook until it boils over a high enough heat, then add the meat to a sprinkling of oil. After sprinkling the oil, reduce the heat using only coconut husk. Then randang cooked for \pm 6 hours until cooked, Randang ready to serve

Combine the coconut milk, spices and leaves that have been mashed, then cook until it boils over a high enough heat, then add the meat to a sprinkling of oil. After 
Bay leaf 2 strands

Turmeric leaves 1 strand

Lime leaves 1 strand

Lemongrass 2 btg

Salt sck
Local chilies $1 / 4 \mathrm{~kg}$

Galangal 2 tbsp

Ginger 1 tbsp

Garlic 2 tbsp

2 ounces of red onion

Bay leaf 4 strands

Turmeric leaves 1 strand

Lime leaves 4 strands

Lemongrass 3 btg

Nutmeg 1 pcs

Clove 5 pcs

Coconut for randang 3 tbsp

Seasoning for goat cooking 1

bks

Salt sck

13. $1 \mathrm{~kg}$ of meat (25 Local chilies 1 ounce

pieces)

Coconut

(mangka)
Galangal 2 thousand

Ginger 2 thousand

Garlic 1 hump

Bay leaf 4 strands

Turmeric leaves 2 strands

Lime leaves 2 strands

Lemongrass 4 btg

Salt sck sprinkling the oil, reduce the heat using only coconut husk. Then the randang is cooked for \pm 6 hours until cooked. If randang wants it to be more delicious, leave the randang for 1 night until the spices soak into the new meat the next day, cook again until the randang is dry, oily and cooked

Randang ready to be served

Saute the spices, spices and mashed leaves and crushed lemongrass until fragrant. Then add the thick coconut milk, stir until it boils, then add the meat until the oil rises. After rising, reduce the fire oil using only coconut husk. Then randang cooked for \pm 3 hours until cooked and ready to serve randang

Combine the coconut milk, spices and leaves that have been mashed, then cook until it boils over a large enough heat, then add the meat to a sprinkling of oil, after sprinkling the oil, reduce the heat using only coconut husk then cook until cooked, if you want more delicious, leave the randang overnight until the spices soak into the new meat the next day it is cooked again until the dry randang is oily and cooked, Randang is ready to serve

Based on the table above, it can be concluded that the randang recipe from Kenagarian Baso uses various ingredients, spices and processing techniques. Where for the ingredients used in the processing of randang in Kenagarian Baso, the average meat in $1 \mathrm{~kg}$ of meat produces 25-30 pieces, for the use of coconut it is 3-5 grains, while the spices and herbs used are local red chilies, garlic, shallots, galangal, ginger, bay leaves, lime leaves, turmeric leaves, lemongrass, salt. 
Table 4. Recipe Inventory Data in Gadut Kenagarian

\begin{tabular}{|c|c|c|c|}
\hline No. & Material & Seasonings & Processing technique \\
\hline 1. & $\begin{array}{l}\text { Beef } 1 \mathrm{~kg}, \\
\text { coconut milk } \\
11 / 2 \mathrm{~kg}\end{array}$ & $\begin{array}{l}\text { Coconut for rrandang } 1 \frac{1}{2} \text { ounce, } \\
1 \text { sck of lime leaves, bay leaves, I } \\
\text { sck of turmeric leaves, one sck of } \\
\text { lemongrass, } 1 \text { head garlic, } 1- \\
\text { ounce red onion, } 2 \text { ounces red } \\
\text { chili, one sck ginger, one sck } \\
\text { galangal, and one sck of salt. }\end{array}$ & $\begin{array}{l}\text { Blend all spices, red chilies except } \\
\text { ginger and galangal crushed. } \\
\text { Add coconut milk, ground spices, } \\
\text { ground red chilies, leaves, coconut for } \\
\text { randang, galangal and crushed ginger } \\
\text { until the oil rises. } \\
\text { Enter the beef cook over low heat for } 3 \\
\text { hours until cooked and blackish brown. }\end{array}$ \\
\hline 2. & $\begin{array}{l}1 \mathrm{~kg} \text { of beef, } \\
(27) \text { coconut } \\
\text { milk, } 3 \\
\text { coconuts }\end{array}$ & $\begin{array}{l}\text { Coconut for randang } 1 \frac{1 / 2}{2} \text { ounce, } 6 \\
\text { pieces of lime leaves, } 5 \text { pieces of } \\
\text { bay leaf, } 2 \text { pieces of turmeric } \\
\text { leaves, } 2 \text { sticks of lemongrass, } 2 \\
\text { heads of garlic, } 1 \text { ounce of red } \\
\text { onion, } 2 \text { ounces of red chilies, } 1 \\
\text { segment of ginger, } 2 \text { segments of } \\
\text { galangal, sck salt, nutmeg } 1 / 3 \\
\text { grains. } 5 \text { cloves, } 4 \text { spices hard, } 1 \\
\text { tablespoon coriander, } 1 \text { star anise, } \\
1 \text { stick of cinnamon. }\end{array}$ & $\begin{array}{l}\text { Blend all the spices, red chilies, lime } \\
\text { leaves, and lemongrass. } \\
\text { Saute ground spices, beef, bay leaves, } \\
\text { saffron leaves and sauteed spices until } \\
\text { fragrant. Remove the meat from the } \\
\text { seasonings. } \\
\text { Add the coconut milk to boil, add the } \\
\text { beef for } 4 \text { hours until cooked and } \\
\text { blackish brown. }\end{array}$ \\
\hline 3. & $\begin{array}{l}\text { Beef } 1 \quad \mathrm{~kg} \\
(25), \text { coconut } \\
\text { milk } \quad 3 \\
\text { coconuts, } \\
\text { coconut } \\
\text { water } \\
\text { coconut. }\end{array}$ & $\begin{array}{l}1 \text { ounce coconut for randang, one } \\
\text { sack of lime leaves, one sack of } \\
\text { bay leaves, one sack of turmeric } \\
\text { leaves, lemongrass, } 11 / 2 \text { head } \\
\text { garlic, } 1 \text {-ounce red onion, } 1 / 4 \mathrm{~kg} \text { of } \\
\text { red chili, } 1 \text { segment ginger, } 2 \\
\text { segment galangal, one sack of } \\
\text { salt. }\end{array}$ & $\begin{array}{l}\text { Puree all spices, and red chilies. } \\
\text { Saute ground spices, ground red chilies, } \\
\text { and leaves until fragrant, add the beef } \\
\text { pieces, mix well. } \\
\text { Add coconut milk and cook until the } \\
\text { meat randang is dark brown for } 3 \\
\text { hours. }\end{array}$ \\
\hline 4. & $\begin{array}{l}\text { Beef } 1 \quad \mathrm{~kg} \\
(25), \text { coconut } \\
\text { milk } 3 \\
\text { coconuts, and } \\
\text { coconut } \\
\text { water one } \\
\text { sack. }\end{array}$ & $\begin{array}{l}1 \text { tbsp coconut for randang, sck } \\
\text { lime leaves, sck bay leaves, sck } \\
\text { turmeric leaves, sck lemongrass, } \\
1 \frac{1 / 2 \text { ounce garlic, } 1 / 4 \mathrm{~kg} \text { of onion, }}{2 \text { ounces red chili, } 1 \text { segment }} \\
\text { ginger, galangal } 11 / 2 \text { ounce, sck } \\
\text { salt, tamarind } 1 \text { bks. }\end{array}$ & $\begin{array}{l}\text { Add the coconut milk, all the spices } \\
\text { and cooking leaves until it boils. } \\
\text { Enter the beef cook over low heat for } 4 \\
\text { hours until it turns blackish brown }\end{array}$ \\
\hline 5. & $\begin{array}{l}\text { Beef } 1 \mathrm{~kg} \\
(30), \text { coconut } \\
\text { milk } 3 \\
\text { coconuts }\end{array}$ & $\begin{array}{l}\text { Coconut for randang } 1 / 2 \text { ounce, sck } \\
\text { lime leaves, bay leaves sck, sck } \\
\text { turmeric leaves, sck lemongrass, } \\
1 / 2 \text { ounce garlic, } 1 \text {-ounce red } \\
\text { onion, } 1 / 2 \text { ounce red chili, } 1 / 2 \text { ounce } \\
\text { ginger, } 1 \text { ounce galangal, sck salt, } \\
1 / 3 \text { nutmeg } 3 \text { eggs, } 3 \text { spices } \\
\text { hardar, } 1 \text { tsp coriander, } 3 \text { pieces } \\
\text { of star anise, } 1 \text { stick of cinnamon. }\end{array}$ & $\begin{array}{l}\text { Saute ground spices, ground chilies } \\
\text { until fragrant } \\
\text { Add the leaves and beef, mix well } \\
\text { Add cooking coconut milk until the oil } \\
\text { rises } \\
\text { Reduce heat, cook for about } 2 \text { hours } \\
\text { until blackish brown }\end{array}$ \\
\hline
\end{tabular}

Based on the table above, it can be concluded that the randang recipe from Gadut Kenagarian uses various ingredients, spices and processing techniques. Where the ingredients used in the processing of randang in Gadut Kenagarian are beef, in $1 \mathrm{~kg}$ of meat it produces 25 
pieces, the coconut used is 3-5 grains, then added with coconut water while for the spices used are local red chilies, garlic., shallots, galangal, ginger, bay leaves, lime leaves, turmeric leaves, lemongrass, salt, nutmeg, coconut for randang and randang spices.

Table 5. Recipe Inventory Data in Kenagarian Duo Koto

\begin{tabular}{|c|c|c|c|}
\hline No. & Material & Spices & Processing technique \\
\hline 1 & $\begin{array}{l}1 \mathrm{~kg} \text { of meat } \\
(25-30) \\
\text { pieces, } \\
\text { coconuts }\end{array}$ & $\begin{array}{l}\text { Milled chilies } 1 / 4 \mathrm{~kg}, \text { ground } \\
\text { chilies } 1 \text { ounce, shallots } 1 / 4 \mathrm{~kg} \text {, } \\
\text { garlic } 1 / 4 \mathrm{~kg}, \text { laos } 1 / 4 \mathrm{~kg}, 1 \mathrm{ons} \\
\text { ginger, } 2 \text { tablespoons of randang } \\
\text { spices, bay leaves, sck salt spices }\end{array}$ & $\begin{array}{l}\text { Clean the meat and cut it, puree the } \\
\text { spices, thinly slice the shallots, saute the } \\
\text { onions until they change color, add the } \\
\text { mashed spices, leaves and spices, after } \\
\text { they are fragrant, add the meat, cover and } \\
\text { let stand } 20 \text { minutes, then remove the } \\
\text { meat from the coconut milk and stir all. } \\
\text { the seasoning is well flat, let it boil, then } \\
\text { add the meat again until it becomes } \\
\text { randang }\end{array}$ \\
\hline 2 & $\begin{array}{l}1 \mathrm{~kg} \text { meat } \\
(30) \text { pieces, } \\
3 \text { coconuts }\end{array}$ & $\begin{array}{l}\text { Milled chilies } 1 / 4 \mathrm{~kg} \text {, shallots } 1 / 4 \\
\mathrm{~kg} \text {, garlic } 1 \text { ounce, laos la kg, } 1 \\
\text { tbsp ginger, } 1 \text { ounce goat } \\
\text { seasoning, bay leaves, sck salt } \\
\text { spices }\end{array}$ & $\begin{array}{l}\text { Clean the meat and cut it, puree the } \\
\text { spices, thinly slice the shallots, saute the } \\
\text { onions until they change color, add the } \\
\text { mashed spices, leaves and spices, after } \\
\text { they are fragrant, add the meat, cover and } \\
\text { let stand } 20 \text { minutes, then remove the } \\
\text { meat from the coconut milk and stir all. } \\
\text { the seasoning is well flat, let it boil, then } \\
\text { add the meat again until it becomes } \\
\text { randang }\end{array}$ \\
\hline 3 & $\begin{array}{l}1 \mathrm{~kg} \text { of meat } \\
(25-30) \\
\text { pieces, } \\
\text { coconuts }\end{array}$ & $\begin{array}{l}\text { Milled chilies } 1 / 4 \mathrm{~kg} \text {, shallots } 1 / 4 \\
\mathrm{~kg} \text {, garlic } 1 \text { ounce, laos la kg, } 1 \\
\text { tbsp ginger, } 1 \text { ounce goat } \\
\text { seasoning, bay leaves, sck salt } \\
\text { spices }\end{array}$ & $\begin{array}{l}\text { Clean the meat and cut it, puree the } \\
\text { spices, thinly slice the shallots, saute the } \\
\text { onions until they change color, add the } \\
\text { mashed spices, leaves and spices, after } \\
\text { they are fragrant, add the meat, cover and } \\
\text { let stand } 20 \text { minutes, then remove the } \\
\text { meat from the coconut milk and stir all. } \\
\text { the seasoning is well flat, let it boil, then } \\
\text { add the meat again until it becomes } \\
\text { randang }\end{array}$ \\
\hline 4 & $\begin{array}{l}1 \mathrm{~kg} \text { of meat } \\
(25-30) \\
\text { pieces, } \\
\text { coconuts }\end{array}$ & $\begin{array}{l}1 \text { pcs of coconut randang, } 2 \\
\text { ounces of ground chilies, } 1 \text { ounce } \\
\text { of cayenne pepper, } 2 \text { ounces of } \\
\text { red onion, } 1 / 2 \text { ounce of garlic, } 1 \\
\text { ounce of laos, } 1 / 2 \text { ounce of ginger, } \\
2 \text { tbsp of randang spices, bay } \\
\text { leaves, lime leaves, clove leaves, } \\
\text { cardamom, skin sweet salt sck }\end{array}$ & $\begin{array}{l}\text { All ingredients are crushed except the } \\
\text { spices and leaves, coconut ginseng and } \\
\text { then grind it, squeeze the coconut, saute } \\
\text { all the ingredients along with all the } \\
\text { leaves and spices, then add the meat, cook } \\
\text { for about } 20 \text { minutes, then remove the } \\
\text { meat, and add the chili sauce to the } \\
\text { coconut milk until smooth, after boil add } \\
\text { the meat, stir again until it becomes } \\
\text { randang, }\end{array}$ \\
\hline 5 & $\begin{array}{lr}1 \quad \mathrm{~kg} & (30) \\
\text { pieces } & \text { of } \\
\text { meat, } & 3 \\
\text { coconuts } & \end{array}$ & $\begin{array}{l}2 \text { ounces of ground chilies, } 2 \\
\text { ounces of red onion, } 1 / 2 \text { ounce of } \\
\text { garlic, } 1 \text { ounce of laos, } 1 / 2 \text { ounce } \\
\text { of ginger, } 2 \text { tbsp of randang } \\
\text { spices, bay leaves, lime leaves, } \\
\text { cloves, kalpulaga, sck cinnamon, }\end{array}$ & $\begin{array}{l}\text { All ingredients are crushed except the } \\
\text { spices and leaves, coconut ginseng and } \\
\text { then grind it, squeeze the coconut, saute } \\
\text { all the ingredients along with all the } \\
\text { leaves and spices, then add the meat, cook } \\
\text { for about } 20 \text { minutes, then remove the }\end{array}$ \\
\hline
\end{tabular}



randang,

Based on the table above, it can be concluded that the randang recipe from Kenagarian Duo Koto uses various ingredients, spices and processing techniques. Where for the ingredients used in the processing of randang in Kenagarian Sungai Tanang, the average beef in $1 \mathrm{~kg}$ of meat produces 25-30 pieces, while for the use of coconut it is 3-5 grains, for the spices and herbs used in this rending processing, namely local red chili, garlic, shallots, galangal, ginger, bay leaves, lime leaves, turmeric leaves, lemongrass, salt, nutmeg, and randang spices.

\section{Conclusion}

Based on the research results, it was concluded that the inventory of randang in Agam Regency as a traditional food. Randang found in Agam Regency has different recipes and processing methods. Randang in Agam Regency as traditional food is served in traditional events such as marriage / weeding event, local traditional events such as batagak pengulu, manta karumah mintuo, manjalang manduo, manjamu datuak, Eid al-Fitr, Eid al-Adha and as daily dishes.

\section{References}

[1] A.Gima dan Sugiaman. 2013. Manajemen Aset Pariwisata Pelayanan Berkualitas agar Wisatawan Puas Dan Loyal. Bandung: Guardaya Intimarta.

[2] Azima, F. (2016). Chemical Characteristic And Fatty Acid Profile In Randang Of Minangkabau. International Journal On Advanced Science, Engineering And Information Technology, 6(4), 465468.

[3] Murdijati, Dkk. 2019. Kuliner Minangkabau. Jakarta: Pt Gramedia Pustaka Utama

[4] Rahmadona, T., Yulastri, A., \& Syarif, W. (2018). INVENTARISASI JENIS DAN RESEP KUEKUE TRADISIONAL DI KABUPATEN PASAMAN BARAT. E-Journal Home Economic and Tourism, 14(1).

[5] Wynda Dwi Amalia. 2019. Randang Bundo. Jakarta: Pt Gramedia Pustaka Utama 